Japan. J. Med. Sci. Biol., 34, 95-102, 1981

\title{
INDUCTION AND CHARACTERIZATION OF SPLENIC SUPPRESSOR CELLS DIRECTED TO NATURAL KILLER CELLS IN JAPANESE QUAILS
}

\author{
Akio YAMADA and MASANORI HAYAMI \\ Department of Measles Virus, National Institute of Health, \\ Musashi-Murayama, Tokyo 190-12, Japan
}

(Received, December 12, 1980. Accepted, February 5, 1981)

\begin{abstract}
SUMMARY: Intravenous inoculation of chicken amniotic fluid (ChAmF) markedly reduced natural killer (NK) cell activity of spleen cells from Japanese quails. The reduction of NK activity was mediated by non-adherent thymus-dependent lymphoid cells which were resistant to treatment with anti-immunoglobulin serum and sensitive to treatment with anti-thymocyte serum in the presence of complement. The suppressing activity was selectively directed to NK cells, since Rous sarcoma virus-specific cytotoxicity or hemagglutinating antibody production against sheep erythrocytes was not suppressed in ChAmF-treated quails. Spleen cells from normal 1-week-old quails had similar characteristics to those from ChAmF-treated 4-week-old quails, lacking NK activity and exhibiting suppressive effect on NK activity, and were also shown to be thymus-dependent. Biological significance of the presence of NK cells and their suppressor cells is discussed in relation to embryonic development and tumor-surveillance mechanism.
\end{abstract}

\section{INTRODUCTION}

It has been well established that various types of suppressor cells, i.e., suppressor T cells (Basten, Loblay and Pritchard-Briscoe, 1977), B cells (Neta and Salvan, 1976) and macrophages (Kirchner, Fernbach and Herberman, 1976) are involved in the regulation of diverse immune responses. As regards the natural killer (NK) cells, little information is available on their regulation by suppressor cells. A few reports demonstrated suppressor cells directed to NK cells (Savary and Lotzva, 1978; Hochman and Cudkowicz, 1979; Santoni et al., 1978).

In a previous paper (Yamada et al., 1980), we demonstrated the presence of NK cells in the spleens of Japanese quails and induction of suppressor cells directed to NK cells by treating quails with chicken amniotic fluid. In the present study, the properties of these suppressor cells including their specificity and sensitivity to several treatments were examined.

山田章雄・速水正憲（国立予防衛生研究所 麻疹ウイルス部） 


\section{Materials ANd Methods}

Animals: Japanese quails (Coturnix coturnix japonica) were obtained from the Nippon Institute for Biological Science, Tokyo, and used at the age of 4 to 8 weeks unless otherwise specified.

Virus and cells: Schmidt-Ruppin strain of subgroup A of Rous sarcoma virus (SR-RSV) was used to infect Japanese quails. Normal quail embryo (nQE) cells, quail embryo cells transformed with SR-RSV (SR-QE), and established quail cell line, $\mathrm{R}(-)$ were used. $\mathrm{R}(-)$ cells were transformed with defective Bryan high-titer strain of RSV lacking gp85, the major envelope glycoprotein.

Treatment of quails with chicken amniotic fluid (ChAmF): Quails were treated with $\mathrm{ChAmF}$ of 8-day-old embryos as described previously (Yamada et al., 1980). In brief, quails received four iv inoculations each with $0.2 \mathrm{ml}$ of ChAmF at 2-day intervals and their spleen cells were assayed for $\mathrm{NK}$ activity 2 days after the last injection.

Assay for NK activity: NK activity was measured as described before by the microcytotoxicity test (Yamada et al., 1980). In brief, target cells prepared in Falcon 3034 microtest plates were incubated with a spleen cell suspension at $39 \mathrm{C}$ for $16 \mathrm{hr}$, and surviving target cells were counted after staining with a $2 \%$ Giemsa solution. Percent cytotoxicity was calculated by the following equation:

Number of cells remaining without effector cells-

Number of cells remaining with effector cells

Number of cells remaining without effector cells $\times 100$

Detection of suppressor cells: Normal spleen cells exhibiting NK activity were mixed with spleen cells taken from test animals and the mixture was assayed for NK activity as mentioned above.

Production of hemagglutinating $(H A)$ antibody to sheep red blood cells $(S R B C)$ : Quails were each intravenously injected with $0.2 \mathrm{ml}$ of $10 \%$ SRBC and sera were collected on day 5 after immunization. HA titers were expressed as the reciprocals of the highest serum dilutions agglutinating $0.4 \% \mathrm{SRBC}$ on microplates.

Treatment of spleen cells: Details of depletion of adherent cells, surface immunoglobulin-bearing cells and thymus-derived cells were described previously (Yamada et al., 1980). Adherent and non-adherent cells were separated by incubating a spleen cell suspension on a plastic dish. Non-adherent cells were further treated with anti-quail immunoglobulin serum (a-Ig) or anti-quail thymocyte serum (ATS) in the presence of guinea-pig complement. The cytotoxic antibody titers were determined by the microcytotoxicity test in the presence of complement and expressed as $50 \%$ effective dose calculated by the method of Behrens-Kärber. The titers of ATS and a-Ig for thymocytes were 512 and 4, respectively, and for bursal cells 16 and 2,048, respectively. 
TABLE I

Influence of $S / E$ ratios on suppressor activity

\begin{tabular}{|c|c|c|c|c|c|}
\hline \multirow{2}{*}{$\begin{array}{l}\text { Number of } \\
\text { effector } \\
\text { cells }\end{array}$} & \multirow{2}{*}{$\begin{array}{l}\text { Number of } \\
\text { suppressor } \\
\text { cells }\end{array}$} & \multirow{2}{*}{ S/E ratio ${ }^{1)}$} & \multicolumn{3}{|c|}{$\%$ cytotoxicity on } \\
\hline & & & nQE & $\mathbf{R}(-)$ & SR-QE \\
\hline $1 \times 10^{4}$ & 0 & 0 & $43.4^{* * * 3)}$ & $59.4^{* * *}$ & $49.2^{* * *}$ \\
\hline $1 \times 10^{4}$ & $0.25 \times 10^{4}$ & 0.25 & $28.3^{* *}(34.8)^{2)}$ & $30.5^{* * *}(48.7)$ & $33.4^{* *}(32.1)$ \\
\hline $1 \times 10^{4}$ & $0.5 \times 10^{4}$ & 0.5 & $8.6 \quad(80.2)$ & $29.0^{* * *}(51.2)$ & $25.3^{* *}(48.6)$ \\
\hline $1 \times 10^{4}$ & $1 \times 10^{4}$ & 1.0 & $13.7 \quad(68.4)$ & $23.7 \quad(60.1)$ & $12.4 \quad(74.8)$ \\
\hline
\end{tabular}

1) Suppressor cell to effector cell ratio.

2) Percent suppression is shown in parentheses.

3) Statistical significance was estimated by Student's $T$ test comparing with control (without the addition of effector cells). ${ }^{* * *} \mathrm{P}<0.001{ }^{* *} \mathrm{P}<0.01$

\section{Results}

\section{Induction of Suppressor Cells to NK Cells}

As previously reported (Yamada et al., 1980), spleen cells of normal quails exhibited NK activity on various target cells of quail origin such as $\mathrm{nQE}, \mathrm{R}(-)$ and SR-QE which expressed embryonic antigen(s) (E-Ag) on their surfaces (Ignjatovic et al., 1978). The NK activity was significantly reduced in quails treated with $\mathrm{ChAmF}$ and the reduction was mediated by suppressor cells induced by ChAmF-treatment. As shown in Table I, such a suppressive effect was manifested at suppressor to effector cell ratios (S/E ratios) of $1: 1,0.5: 1$ and $0.25: 1$. The ratio of $1: 1$ was employed in the following experiments.

\section{Specificity of Suppressor Cells}

To investigate whether the suppressive effect was directed to only NK cell activity, the effect of ChAmF-treatment on RSV-specific cell-mediated cytotoxicity was examined. Quails treated with ChAmF were infected with 1,000 focus-forming units of SR-RSV. Two weeks after RSV infection, quails with progressing tumor (progressor) and those with regressing tumor (regressor) were sacrificed and their spleen cells were tested for the cytotoxicity (Table II).

Regressor spleen cells without ChAmF-treatment manifested high cytotoxicity on SR-QE and $\mathrm{R}(-)$ cells, and low but significant cytotoxicity on $\mathrm{nQE}$ cells. The cytotoxicity on the formers was considered to be due to both RSVspecific immune lymphocytes and NK cells, whereas on the latters was it considered to be due to only NK cells. In progressors without ChAmF-treatment, the cytotoxicity on SR-QE and $\mathrm{R}(-)$ cells was reduced to the levels close to that of normal spleen cells. As RSV-specific cytotoxicity was not detected in progressor lymphocytes (Hayami et al., 1972), such a low level of the cytotoxicity detected in progressor spleen cells was considered to be mediated by NK cells. This was confirmed by the finding that spleen cells from the progressors treated 
TABLE II

Effect of ChAmF-treatment on RSV-specific cell-mediated cytotoxicity

\begin{tabular}{cclccc}
\hline \multirow{2}{*}{$\begin{array}{c}\text { ChAmF- } \\
\text { treatment }\end{array}$} & $\begin{array}{l}\text { RSV- } \\
\text { immunization }\end{array}$ & & \multicolumn{3}{c}{$\%$ cytotoxicity on } \\
\cline { 4 - 6 } & & & nQE & SR-QE & R $(-)$ \\
\hline+ & + & Prog. $\left.{ }^{2}\right)$ & -14.2 & 3.8 & 7.7 \\
+ & + & Reg..$^{3)}$ & -19.3 & $77.9^{* * * 44}$ & $51.2^{* * *}$ \\
- & + & Prog. & $19.1^{*}$ & $35.5^{* * *}$ & $16.0^{*}$ \\
- & + & Reg. & $17.9^{*}$ & $55.3^{* * *}$ & $42.7^{* * *}$ \\
- & - & & 17.2 & $23.3^{*}$ & $28.3^{* * *}$ \\
+ & - & & -0.2 & 9.9 & 19.8 \\
\hline
\end{tabular}

1) Spleen cells were obtained from quails immunized with 1,000 FFU of SR-RSV 2 weeks before and assayed for their cytotoxicity by the microcytotoxicity test.

2) Progressor spleen cells.

3) Regressor spleen cells.

4) Statistical significance was estimated by the Student's $T$ test. ***P $<0.001 * \mathrm{P}<0.05$

TABLE III

Hemagglutinating antibody titers to $S R B C^{1)}$

\begin{tabular}{lccc}
\hline \multicolumn{1}{c}{ Quails } & Positive ratio & HA titers \\
\hline ChAmF-treated & $5 / 5^{2)}$ & $32,128,128,>256,>256$ \\
Untreated & $5 / 5$ & $128,32,16,128,64$ \\
\hline
\end{tabular}

1) Sera were collected from quails immunized with $10 \% \mathrm{SRBC}$ 5 days before. Hemagglutinating (HA) antibody titers were expressed as the resiprocals of the highest dilutions agglutinating $0.4 \%$ SRBC on microplates.

2) Number positive/Number tested.

with ChAmF showed no cytotoxicity on SR-QE and $\mathrm{R}(-)$ cells or $\mathrm{nQE}$ cells. On the other hand, spleen cells of regressors with ChAmF-treatment showed high cytotoxicity on SR-QE and $\mathrm{R}(-)$ cells but not on $\mathrm{nQE}$ cells. In vitro experiments revealed that the cytotoxicity of RSV-immune spleen cells on SR-QE or $\mathrm{R}(-)$ cells was not suppressed even after the addition of spleen cells from ChAmF-treated quails, whereas that on $\mathrm{nQE}$ cells was suppressed (data not shown). These findings suggest that ChAmF-treatment suppresses only NK cell activity but not antigen-specific cytotoxic responses.

Moreover, when HA antibody titers against SRBC in ChAmF-treated quails were compared with those in untreated quails, it is evident from Table III that the production of antibodies was not suppressed but rather slightly enhanced by treatment with ChAmF. These findings suggest that suppressor cells induced by treatment with $\mathrm{ChAmF}$ in quails manifest suppressive effect selectively on NK cell activity. 
TABLE IV

NK activity of spleen cells from ChAmF-treated quails after various treatments ${ }^{1)}$

\begin{tabular}{lcc}
\hline \multirow{2}{*}{ Spleen cells } & \multicolumn{2}{c}{$\%$ cytotoxicity on $\mathrm{nQE}$} \\
\cline { 2 - 3 } & Exp. 1 & Exp. 2 \\
\hline Unfractionated & -13.0 & 2.3 \\
Adherent & 1.2 & 13.2 \\
Non-adherent & -9.5 & 2.4 \\
ATS-treated non-adherent ${ }^{2)}$ & $33.6^{* *}$ & $35.4^{* * *}$ \\
a-Ig-treated non-adherent ${ }^{3)}$ & -6.0 & -0.5 \\
NRS-treated non-adherent ${ }^{4)}$ & -4.6 & 8.9 \\
\hline
\end{tabular}

1) Spleen cells of ChAmF-treated quails were separated into adherent and non-adherent cells. Both fractions were assayed for their cytotoxicity. Non-adherent cells were further processed by several treatments and then assayed for the cytotoxicity.

2) Anti-thymocyte serum plus complement.

3) Anti-immunoglobulin serum plus complement.

4) Normal rabbit serum plus complement.

*** $\mathrm{P}<0.001{ }^{* * *} \mathrm{P}<0.01$ (compared with the value obtained without the addition of effector spleen cells)

\section{Characterization of Suppressor Cells}

To determine the cell types displaying suppressive effect on NK cells, we examined the effect of several treatments on the function of ChAmF-induced suppressor cells. First, spleen cells from ChAmF-treated quails, which had no cytotoxic activity, were separated into adherent and non-adherent cells. Both fractions showed no apparent cytotoxicity, but non-adherent cells exerted NK activity after treatment with ATS in the presence of complement. On the other hand, depletion of surface immunoglobulin-bearing cells from ChAmF-treated spleen cells by treatment with a-Ig and complement failed to manifest NK activity. These results suggest that the suppressor cells were non-adherent, thymus-dependent cells (Table IV).

To confirm this finding that the suppressor cells were thymus-dependent, cell mixture experiment was performed (Table V). Spleen cells from normal quails showing NK activity were mixed with various preparations of spleen cells of ChAmF-treated quails. As shown in the table, the addition of adherent cells or ATS-treated non-adherent cells taken from ChAmF-treated quails did not eliminate the cytotoxic activity of normal spleen cells. No other treatments interfered with suppressive effect of ChAmF-treated spleen cells and NK activity of normal spleen cells was suppressed when they were mixed. It was concluded that suppressor cells are thymus-dependent non-adherent lymphoid cells. 
TABLE V

NK activity of normal spleen cells after mixing with various preparations of spleen cells taken from ChAmF-treated quails

\begin{tabular}{llcc}
\hline \multirow{2}{*}{ Effector } & \multirow{2}{*}{$\begin{array}{l}\text { Preparations of spleen cells } \\
\text { of ChAmF-treated quails }\end{array}$} & \multicolumn{2}{c}{$\%$ cytotoxicity on } \\
\cline { 3 - 4 } & & $\mathrm{nQE}$ & $\mathrm{R}(-)$ \\
\hline Normal spleen cells & - & $43.5^{* * *}$ & $34.4^{* * *}$ \\
Normal spleen cells & Unfractionated & $13.0^{*}$ & 8.3 \\
Normal spleen cells & Adherent & $36.0^{* * *}$ & $47.8^{* * *}$ \\
Normal spleen cells & Non-adherent & 5.0 & $14.7^{*}$ \\
Normal spleen cells & ATS-treated non-adherent & $33.3^{* * *}$ & $45.5^{* * *}$ \\
Normal spleen cells & a-Ig-treated non-adherent & 10.1 & 4.8 \\
Normal spleen cells & NRS-treated non-adherent & 6.8 & 4.9 \\
\hline
\end{tabular}

*** $\mathrm{P}<0.001 * \mathrm{P}<0.05$ (compared with the value obtained without the addition of effector cells)

TABLE VI

NK activity of spleen cells from 1-week-old quails

\begin{tabular}{ccc}
\hline $\begin{array}{l}\text { Spleen cells taken } \\
\text { from quails aged } \\
\text { (in weeks) }\end{array}$ & Treatment & $\%$ cytotoxicity ${ }^{1)}$ \\
\hline 1 & - & 6.2 \\
4 & - & $33.3^{* * *}$ \\
$1+4^{2)}$ & - & 6.4 \\
1 & ATS $+\mathrm{CC}^{3)}$ & $39.1^{* * *}$ \\
\hline
\end{tabular}

1) $\mathrm{R}(-)$ cells were used as target cells.

2) After spleen cells from 1-week-old quails and from 4-week-old ones were mixed at a ratio of $1: 1$, the cytotoxicity of the mixture was assayed.

3) Anti-thymocyte serum plus complement

*** $\mathrm{P}<0.001$ (compared with the value obtained without the addition of effector spleen cells).

\section{Suppressor Cells in the Spleens of 1-week-old Quails}

In the previous report (Yamada et al., 1980), NK activity was not demonstrated in spleen cells from 1-week-old quails. As shown in Table VI, the lack of NK activity in infant birds was due to the presence of suppressor cells, since the addition of spleen cells from 1-week-old quails to those from 4-week-old ones reduced the cytotoxicity of the latters. Moreover, NK activity of spleen cells from l-week-old quails became detectable after the treatment with ATS and complement. This indicates that the treatment with ATS eliminated ATSsensitive suppressor cells from spleen cells of l-week-old quails. Thus the presence of suppressor cells resembling those of ChAmF-treated quails but not absence of NK cells was suggested as the cause of the lack of NK activity in infant quails. 


\section{Discussion}

By inoculating ChAmF into Japanese quails, we induced thymus-dependent suppressor cells which selectively inhibited NK activity manifested by normal quail spleen cells.

Recently the demonstration of suppressor cells of which effect is directed to NK cells has been documented by several investigators. Savary and Lotzva (1978) reported the presence of suppressor cells for NK cells in the spleens of infant mice, Corynebacterium parvum-injected mice and bone marrow-tolerant mice, however no further characterization of these suppressor cells was informed. Hochman and Cudkowicz (1979) induced suppressor cells for NK cells by treating mice with hydrocortisone and showed that cells responsible for the suppression had extraordinary characteristics in that they could be removed by carbonyl iron but not by other adherence techniques. More recently, it was shown that splenic NK activity was transiently suppressed by activated macrophages in adriamycin-treated mice (Santoni et al., 1980). Thus most of these studies suggested a possible involvement of cells of macrophage lineage as the suppressors. In contrast, the present study disclosed that suppressor cells induced by treatment with ChAmF were thymus-derived lymphoid cells, since their effect was eliminated by treatment with ATS and complement. It seems of interest that NK cells might be regulated not only by macrophage series but also by $\mathrm{T}$ cell lineage. Suppressor $\mathrm{T}$ cells described here have a unique property in comparison with so-called suppressor T cells (Basten et al., 1977; Gershon, 1974) found in mammals in that they are induced by ChAmF and that their action is directed to NK cells selectively. It can be considered that they also differ from suppressor cells suppressing RSV-specific cellular cytotoxicity detected in Japanese quails (Hayami et al., 1972; Bauer, Hayami and Stehfen-Gervinus, 1979).

In the previous paper (Yamada et al., 1980), NK cells were suggested to exert their cytotoxic activity to embryonic antigen(s) (E-Ag) on the target cells. The inhibition of NK activity by the administration of ChAmF may indicate a possibility that E-Ag present in ChAmF directly blocked NK activity rather than by the induction of suppressor cells. This possibility, however, seems unlikely, since the addition of ChAmF to normal spleen cells in vitro did not inhibit NK cell activity of these cells (unpublished data).

Although the mechanism of suppression is still an open question, we consider that the suppression might occur in the effector phase, since a normal level of NK activity was recovered in spleen cells from which suppressor cells were eliminated by treatment with ATS and complement (Table IV). Whether the suppression is manifested by direct cell-to-cell interaction or indirectly by soluble factors as indicated in other systems (Kontiainen and Feldmann, 1977; Tada, Taniguchi and David, 1976) is a subject for further analysis.

Since E-Ag is demonstrated both in embryonic cells and tumor cells (Ignjatovic et al., 1978; Yoshikawa, Ignjatovic and Bauer, 1979), E-Ag-specific 
NK cells and their suppressor cells may be teleologically speculated to participate in both normal embryonic development and tumorigenesis. The presence of suppressor cells at embryo and infant stages may protect the normal embryonic cells from the destruction by NK cells, whereas NK cells may exert cytotoxic activity by recognizing E-Ag expressed on the surface of tumor cells in adult hosts in which suppressor cells are absent.

\section{ACKNOWLEDGEMENT}

We thank Mrs. Michiko Hishiyama, Department of Measles Virus, NIH, for her excellent technical assistance and Dr. Kazuya Yamanouchi for critical reading of the manuscript.

This work was supported in part by Grant-in-Aid for Cancer Research from the Ministry of Education, Science and Culture, Japan.

\section{REFERENCES}

Basten, A., Loblay, R. and Pritchard-Briscoe, H. (1977): T cell dependent suppression of the immune responses. p. 358-368 In Progress in Immunology III., North-Holland Publishing Company, New York.

Bauer, H., Hayami, M. and Stehfen-Gervinus, J. C. (1979): Influence of different routes of anti-tumor immunization: Alternative induction of tumor immunity and tumor enhancement. J. Immunol., 122, 806-812.

Gershon, R. K. (1974): T cell control of antibody production. Contemp. Top. Immunobiol., 3 , $1-40$.

Hayami, M., Hellström, I., Hellström, K. E. and Yamanouchi, K. (1972): Cell-mediated destruction of Rous sarcomas in Japanese quails. Int. J. Cancer, 10, 507-517.

Hochman, P. S. ANd Cudkowicz, G. (1979): Suppression of natural cytotoxicity by spleen cells of hydrocortisone-treated mice. J. Immunol., 123, 968-976.

Ignjatovic, J., Rübsamen, H., HAyami, M. ANd BaueR, H. (1978): Rous sarcoma virus-transformed avian cells express four different cell surface antigens that are distinguishable by a cell-mediated cytotoxicity blocking test. J. Immunol., 120, 1663-1668.

Kirchner, H., Fernbach, B. R. and Herberman, R. B. (1976): Macrophages suppressing T and $\mathrm{B}$ cell mitogen responses and the mixed leukocyte reaction. p. 495-502 In J. J. Oppenheim and D. L. Rosenstreich (eds.), Mitogens in Immunobiology. Academic Press, New York.

Kontiainen, S. And Feldmann, M. (1978): Suppressor cell induction in vitro. IV. Target of antigen-specific suppressor factor and its genetic relationship. J. Exptl. Med., 147, 110-122.

Neta, R. And Salvan, S. B. (1976): $T$ and B lymphocytes in the regulation of delayed hypersensitivity. J. Immunol., 117, 2014-2020.

Santoni, A., Riccardi, C., Sorci, V. and Herberman, R. B. (1980): Effect of adriamycin on the activity of mouse natural killer cells. J. Immunol., 124, 2329-2335.

SAvary, C. A. AND Lotzova, E. (1978): Suppression of natural killer cell cytotoxicity by splenocytes from Corynebacterium parvum-injected, bone marrow-tolerant and infant mice. J. Immunol., 120, 239-243.

Tada, T., Taniguchi, M. And David, C. S. (1976): Properties of the antigen-specific suppressive T-cell factor in the regulation of antibody response of the mouse. IV. Special subregion assignment of the gene(s) that codes for the suppressive $\mathrm{T}$-cell factor in the $\mathrm{H}-2$ histocompatibility complex. J. Exptl. Med., 144, 713-724.

Yamada, A., Hayami, M., Yamanouchi, K. And Fujiwara, K. (1980): Detection of natural killer cells in Japanese quails. Int. J. Cancer, 26, 381-385.

Yoshikawa, Y., Ignjatovic, J. AND Bauer, H. (1979): Tissue-specific expression of onco-fetal antigens during embryogenesis. Differentiation, 15, 41-45. 